\title{
OBECNOŚĆ I ROLA AUDIODESKRYPCJI JAKO WIZERUNEKU AUDIALNEGO MEDIUJĄCEGO W AKCIE KOMUNIKACYJNYM: BADANIE PILOTAŻOWE
}

\author{
KAMILA MIKOŁAJCZYK \\ JOANNA PUPPEL
}

\begin{abstract}
Audiodescription is a type of translation in which visual elements are transferred into verbal descriptions. Numerous studies discuss the influence of this additional narration on media accessibility for its target audiences, namely partially sighted and blind people. Nevertheless, the impact of audiodescription on different audiences, such as sighted people, is still underdeveloped. The aim of this article is to investigate the influence of audiodescription which can be considered an example of mediation in the act of communication, on sighted audiences.
\end{abstract}

Key words: audiodescription, image, audio image

\section{Audiodeskrypcja w akcie komunikacyjnym}

Audiodeskrypcja jest procesem, na który spojrzeć można z perspektywy aktu komunikacyjnego. Opisywana jest między innymi jako wyjątkowy rodzaj komunikacji, przez swoją formę zapewnia dostęp do treści audiowizualnych osobom z niepełnosprawnością wzrokową (zob. Perego, 2016). Stanowi ona proces, który jest przykładem komunikacji jednokierunkowej, w której nadawca przekazuje informacje do odbiorcy celem osiągnięcia odpowiedniego efektu. Efektem tym jest odbiór wszelkiego rodzaju treści wizualnych, na przykład filmu, który jest możliwie najbardziej zbliżony do odbioru przez osoby widzące. Taka forma, skupiająca się wyłą- 
czenie na efekcie końcowym, nie wymaga generowania informacji zwrotnej ze strony odbiorcy (zob. Emmitt i Gorse, 2009).

Za nadawcę wiadomości w przypadku audiodeskrypcji uznać można twórców filmu - na przykład scenarzystę, który jest „(...) jednym z naczelnych twórców dzieła filmowego (...)" (Hendrykowski, 2018: 39). Przekaz, będący treścią filmu, kierowany jest do odbiorcy, czyli widowni. Jak zostało wcześniej wspomniane, zgodnie z założeniem audiodeskrypcji, widownię stanowią przede wszystkim osoby z niepełnosprawnością wzrokową (Perego, 2016).

Ze względu na specyfikę omawianego rodzaju thumaczenia audiowizualnego, w celu umożliwienia odbioru filmu przez niewidzącą publiczność, konieczna jest obecność mediatora. W przypadku filmów z dodatkową narracją rolę tę pełni audiodeskryptor. Warto zaznaczyć, że zarówno w przypadku audiodeskrypcji, jak i mediacji prowadzonej w każdej innej sytuacji komunikacyjnej, zauważyć tu można wcześniej wspomniany społeczny wymiar tego działania, bez którego strony nie byłyby w stanie skutecznie się porozumieć ze względu na ograniczenia, którymi w tym przypadku są liczne odmiany niepełnosprawności wzrokowej (Janowska, 2017).

Elementami mediacji występującymi w audiodeskrypcji filmu są wszystkie jego wizualne aspekty, które w tym procesie przekształcane są na słowa/frazy. Wśród nich wymienić można między innymi wygląd bohaterów, scenerię czy mowę ciała, czyli całą ekspresję niewerbalną (Hirvonen i Tiittula, 2010).

Audiodeskryptor pośrednicząc $\mathrm{w}$ przekazie informacji, czyli opisując wyżej wymienione elementy, musi spełniać odpowiednie wymogi. I tak, jak każdy inny mediator w procesie komunikacyjnym, musi być on neutralny i bezstronny, jako, że stworzona przez niego audiodeskrypcja winna spełniać wymogi obiektywizmu (Limbach, 2015: 142). Zastosowanie ma tu zasada What You See Is What You Say (Mówisz to co widzisz), według której powstały skrypt zawiera jedynie opis tego, co widoczne jest na ekranie, bez dodatkowej interpretacji ze strony audiodeskryptora (Snyder, 2008). Co więcej, osoba tworząca audiodeskrypcję, podobnie jak każdy inny mediator, musi odpowiednio dostosować stworzony przez nadawcę przekaz do wymogów odbiorców - w tym przypadku do konkretnego rodzaju widowni z dysfunkcją wzroku. Możliwe jest to poprzez stosowanie takich zasad jak opis od ogółu do szczegółu czy stosowanie odpowiedniego języka, który charakteryzuje się wysokimi zasobami językowymi (Künstler et al., 2012).

W filmie, który zaopatrzony jest dodatkową narracją, czyli wizualne informacje są wzbogacone o dodatkowy kanał komunikacyjny, audiodeskrypcja ma za zadanie uzupełniać i tworzyć spójną całość. Spójność ta polega na tym, że modalność wizualna, która jest obecna w utworze audiowizualnym przez cały czas, w odpowiednich momentach zostaje zwerbalizowana celem stworzenia modeli umysłowych możliwie jak najbardziej zbliżonych do modeli tworzonych przez osoby widzące (Braun, 2007; Sadowska, 2014). 
Biorąc pod uwage pozostałe komponenty aktu komunikacyjnego, w audiodeskrypcji również możliwe jest wystąpienie szumu, który zakłóca odbiór filmu. Przykładem takich zakłóceń może być, między innymi zbyt szybkie czytanie przez audiodeskryptora skryptu (Szarkowska i Künstler, 2012) lub zbytnia szczegółowość opisu, którą tu możemy nazwać również szumem informacyjnym (zob. Shannon i Weaver, 1949).

Pozostaje zaznaczyć ważną funkcję audiodeskrypcji, pokrywającą się jednocześnie z celem procesu komunikacyjnego, którym jest „,...) doprowadzenie do właściwego rozumienia i interpretacji wzajemnych przekazów i ich kontekstów" (Kalisz i Zienkiewicz, 2014: 44). Uznać bowiem można, że dzięki temu rodzajowi thumaczenia nie tylko nadawca komunikatu, czyli twórca filmu, osiągnie zamierzony efekt, którym jest dodarcie do jak najszerszej publiczności. To przede wszystkim odbiorcy audiodeskrypcji odnoszą korzyści w postaci dostępu do, będącej dotychczas poza ich zasięgiem, produktów kultury. Ma to nieodzowny wpływ na podkreślaną przez Janowską (2017: 80) autentyczną komunikację osób niewidomych ze światem zewnetrznym. Bez charakterystycznego dla audiodeskrypcji pośredniczenia w przekładzie elementów wizualnych na dźwiękowe, ta likwidacja barier komunikacyjnych nie byłaby możliwa.

\section{Wizerunek audialny}

Wizerunek określany jest jako cielesność, która

[j]ako fizyczność jest (...) jednocześnie obdarzona własnością niejako janusowej „,aparycji”, tj. zarówno „wyglądem” jak i „oglądem”, a więc wyposażeniem jej w różnorakie atrybuty nadawczo-odbiorcze, $\mathrm{i}$ - co się z tym wiąże - nieuniknioną koniecznością wysyłania wyglądu na zewnątrz (tj. ruchu od danej cielesności ku innym cielesnościom) a także nieuniknioną koniecznością odbierania wyglądu (czyli oglądu) przez inne cielesności (tj. ruchu ku danej cielesności), tj. postrzegania jej przez inne cielesności właśnie poprzez odwołanie się do tychże atrybutów (Puppel, 2016: 109).

Każdy człowiek nieprzerwanie i za wszelką cenę dąży do tego, by owa aparycja, którą wytwarza, była dla niego korzystna (Puppel, 2016). Z kolei przez inne osoby odbierana jest ona w sposób subiektywny jako obraz, który powstaje na podstawie wybiórczego przyswojenia pewnych cech, wyglądu oraz zachowania (Kowalewska i Puppel, 2017).

Nie inaczej jest $\mathrm{w}$ przypadku filmu $\mathrm{z}$ audiodeskrypcją, w którym za pomocą słów konieczne jest stworzenie odpowiedniego wizerunku ekranowych bohaterów celem stworzenia tychże obrazów. Tu wskazać należy na istotną rolę głosu audiodeskryptora, który tworzy wizerunek audialny, zwany także wizerunkiem dźwięcznym (zob. Pązik, 2008). Jest on jednym z pięciu rodzajów wizerunku, spośród których 
wymienić można także wizerunek plastyczny, piśmienniczy, maskę artystyczną oraz 'bodyart' i obejmuje on właśnie głos człowieka (patrz Ślęzak, 2009). Co więcej, głos, który wpływa na wytworzenie konkretnego wizerunku może być kształtowany przez szereg czynników, takich jak tonacja, brzmienie głosu, specyficzna barwa, czy sposób wysławiania się.

Zgodnie z definicją to głos danego człowieka tworzy jego wizerunek i wpływa na jego rozpoznawalność (Ślęzak, 2009: 17-18). Biorąc jednak pod uwagę specyfikę audiodeskrypcji, która jest mediacją jaka zachodzi pomiędzy twórcą filmu przekazującym jego treść, a widzami za pośrednictwem audiodeskryptora, dojść można do wniosku, że osoba tworząca dodatkową narrację swoim głosem tworzy nie swój własny wizerunek audialny, lecz bohaterów filmu. Przesłanką, która wskazywałaby na taki stan rzeczy jest dążenie do niewidzialności audiodeskryptora. Innymi słowy, głos osoby odpowiedzialnej za tworzenie skryptu audiodeskrypcji powinien być neutralny i nieodwracający uwagi widzów od fabuły filmu oraz wizerunku jego bohaterów (Iglesias Fernández et al., 2015: 77). Co za tym idzie, niezauważenie przez widzów osoby audiodeskryptora powinno być dla niego największym wyróżnieniem i celem (Künstler, 2014).

Niestety, mimo iż naukowcy dostrzegają potencjał wymiaru werbalnego oraz jego roli jaką odgrywa będąc mediatorem $\mathrm{w}$ tworzeniu wizerunku, obecnie niewiele jest wzmianek i badań analizujących te zagadnienia (Iglesias Fernández et al, 2015).

\section{Przedmiot i cel badania}

Organizacja pokazów filmowych dla niewidomych żołnierzy opisywana w artykule z 1917 roku, który uważany jest za pierwszą oficjalną wzmiankę o audiodeskrypcji, (Fryer, 2016: 15) wskazuje, że od samego początku głównym założeniem tego rodzaju thumaczenia było dostarczanie treści wizualnych osobom, które dotychczas ze względu na swoją niepełnosprawność wzrokową nie miały do nich dostępu. Naukowcy również są zgodni w kwestii klasyfikacji osób należących do grupy docelowej audio deskrypcji (AD), co widoczne jest w licznych publikacjach naukowych (zob. Hyks, 2005, Chmiel i Mazur, 2012, Bardini, 2017, Orero, 2012, Puigdomènech et al., 2010). Zgodnie z ustaleniami są to osoby niewodowe i słabowidzące, które według statystyk Światowej Organizacji Zdrowia (WHO) stanowią ponad 285 milionów ludzi na całym świecie.

Jednak według Snyder’a (2008) liczba potencjalnych odbiorców audiodeskrypcji jest znacznie większa i wychodząca poza ogólno przyjęty schemat. Wśród nich Snyder wymienia ludzi z innymi niepełnosprawnościami, nie tylko wzrokowymi. Co więcej, zaznacza, że AD może być również pomocna dla gospodyń domowych, które mogą jednocześnie oglądać film i wykonywać wszelkie prace domowe (Snyder, 2008: 193). Dodatkowo, biorąc także pod uwagę badania przeprowadzone przez 
Rabbitt i Carmichael (1995), do grupy potencjalnych odbiorców AD zaliczyć można także osoby starsze, jako, że pozytywnie reagowały one na obecność dodatkowej narracji podczas oglądania programu telewizyjnego zaprezentowanego w ich eksperymencie.

Opisy te jednoznacznie wskazują na to, że oprócz głównej grupy docelowej, czyli osób z niepełnosprawnością wzrokową, z audiodeskrypcji teoretycznie mogą korzystać także osoby widzące. Podkreśla to również Jankowska (2009), według której to osoby niecierpiące na dysfunkcje wzroku stanowią najliczniejszą grupę odbiorców audiodeskrypcji. Niestety, istnieją jedynie nieliczne prace badające wpływ dodatkowej narracji na osoby bez niepełnosprawności wzrokowej - wśród nich wymienić można badanie dotyczące odbioru filmów z AD przez osoby widzące (Perego, 2016) oraz wpływ AD na naukę języka nierodzimego (Sadowska, 2015). Ze względu na dotychczasowe małe zainteresowanie powyższą tematyką, przedmiotem tego artykułu jest analiza wpływu dodatkowej narracji na efektywność odbioru treści przez osoby widzące. Badanie przeprowadzone opiera się na obecności i roli audiodeskrypcji w utworze audiowizualnym, jakim jest film.

W celu sprawdzenia znaczenia obecności i roli audiodeskrypcji w filmie przeznaczonym dla osób widzących, artykuł postawił sobie następujące założenia:

Z-1: Czy audiodeskrypcja stanowi element mediujący, który korzystnie wpływa na przyswojenie widzącym uczestnikom aktu komunikacyjnego treści przedstawionych w filmie?

Z-2: Wprowadzenie do sceny filmu elementu mediującego $\mathrm{w}$ postaci audiodeskrypcji korzystnie wpływa na odbiór i treści zawarte w filmie przez widzącego uczestnika aktu komunikacyjnego.

\section{Opis badania}

W badaniu wzięło łącznie udział 51 osób, z czego 58\% stanowiły kobiety, a 42\% mężczyźni. Przedział wiekowy uczestników wyniósł od 15 do 78 lat i w badaniu osoby te zostały podzielone na sześć grup wiekowych: grupa 1 - 15-19 lat; grupa 2-20-29 lat; grupa 3-30-39 lat; grupa 4-40-49 lat; grupa 5-50-59 lat i grupa $6-60+$.

Aby zbadać wpływ AD na osoby widzące, konieczne było przeprowadzenie analizy porównawczej. W tym celu uczestnicy zostali losowo podzieleni na dwie grupy. Decyzja o doborze losowym podyktowana była stworzeniem warunków, w których każda z osób badanych miała jednakowe szanse na trafienie do jednej z grup eksperymentalnych.

Grupa pierwsza, która oglądała fragment filmu z AD, liczyła 26 osób. Grupa druga, oglądająca scenę bez dodatkowej narracji, czyli bez AD składała się z 25 osób. 


\subsection{Procedura badawcza}

Pierwszym etapem badania było zgromadzenie osób biorących udział w badaniu i przydzielane ich losowo do jednej z dwóch grup badawczych. Uczestnikom przypisanym do grupy pierwszej zlecone było obejrzenie fragmentu filmu, który zawierał dodatkową narrację - audiodeskrypcję. Zadaniem osób będących w grupie drugiej było obejrzenie tego samego fragmentu bez dodatkowej ścieżki dźwiękowej.

Materiałem filmowym wykorzystanym do badania była scena z filmu Imagine (2012) roku w reżyserii Andrzeja Jakimowskiego. W wybranym fragmencie dwójka głównych bohaterów, Eva i Ian, znajdują się w sklepie obuwniczym. Niewidoma para w towarzystwie ekspedientki wybiera dla kobiety parę butów, która ułatwiałaby jej poruszanie się po mieście. Scena trwa jedynie minutę, jednak szczegółowość tej sceny umożliwi zbadanie ilości zapamiętanych przez widzów informacji.

Narzędziem umożliwiającym takie badanie było stworzenie dwóch wersji ankiety zawierających zestaw pytań otwartych i zamkniętych mających za zadanie zebrać dane osób badanych, sprawdzić ilość zapamiętanych informacji oraz poziom zadowolenia po obejrzeniu materiału filmowego. Obydwie wersje ankiet zawierały ten sam zestaw ośmiu pytań, jedyną różnicą było dodatkowe pytanie $\mathrm{w}$ grupie $\mathrm{z}$ audiodeskrypcją mające na celu zebranie opinii na temat obecności dodatkowej narracji we fragmencie utworu. Wybór omówionego narzędzia pozwolił również na późniejsze przeprowadzenie analizy porównawczej odpowiedzi udzielanych w wyselekcjonowanych grupach badawczych.

\subsection{Ankieta 1 - wersja $\mathrm{z}$ audiodeskrypcją}

Pierwsza wersja ankiety przeznaczona była dla osób, które losowo przydzielone zostały do grupy oglądającej scenę filmu zawierającą dodatkową narrację. Ankieta składała się z czterech pytań, w tym jedno z nich było pytaniem wykorzystującym tzw. pięciostopniową skalę Likerta, dwa pytania otwarte oraz jedno pytanie zamknięte.

\subsubsection{Pytanie ankietowe nr 1}

W pytaniu pierwszym wykorzystana została pięciostopniowa skala Likerta. Zawierała ona dziesięć różnych przymiotników, zarówno pozytywnych jak i negatywnych, co miało pomóc w ustaleniu nastawienia i odczuć osób badanych po obejrzeniu sceny z AD. Średnia arytmetyczna wyników dla poszczególnych przedziałów wiekowych przedstawiona jest w tabeli poniżej (patrz Tabela 1). 
Tabela 1. Ankieta 1 - Pytanie nr 1a (skala Likerta)

\begin{tabular}{|l|c|c|c|c|c|c|}
\hline & $15-19$ & $20-29$ & $30-39$ & $40-49$ & $50-59$ & $60+$ \\
\hline Interesujący & 4 & 3,75 & 3,6 & 3,25 & 4,25 & 4,67 \\
\hline Nużący & 1 & 1,88 & 2,2 & 1,75 & 1 & 1 \\
\hline Irytujący & 1,5 & 2,13 & 2,6 & 1,75 & 1,75 & 1 \\
\hline Wciągający & 4 & 3,75 & 3,4 & 3,5 & 4,75 & 4,67 \\
\hline Przyjemny & 3,5 & 3,62 & 3,4 & 3,25 & 4,5 & 4,67 \\
\hline Wolny & 1 & 1,75 & 2,2 & 2,25 & 1 & 1 \\
\hline Gwałtowny & 3,5 & 1 & 1,4 & 1 & 2 & 2 \\
\hline Ciężki & 3,5 & 1,38 & 1,8 & 1 & 1,5 & 2 \\
\hline Krótki & 5 & 3,38 & 2,6 & 2 & 4,5 & 1,33 \\
\hline Długi & 1 & 1,5 & 2,2 & 2,5 & 1 & 1 \\
\hline
\end{tabular}

Biorąc pod uwagę najwyższe wyniki w obrębie danego przymiotnika, osoby w przedziale wiekowym 60+ stanowily najliczniejszą grupę, która opisywała scenę jako interesująca i przyjemną. Słowo wciagający najczęściej było wybierane przez osoby w wieku 50-59. Według osób w grupie wiekowej 40-49 obejrzana scena była przede wszystkim wolna i dluga, natomiast nużaca i irytująca była dla badanych w wieku 30-39 lat. Najmłodsza grupa wiekowa, 15-19, określała film jako gwattowny, ciężki oraz krótki.

\subsubsection{Pytanie ankietowe $\mathrm{nr} 2 \mathrm{a}$}

Pytanie drugie było pytaniem mającym za zadanie ustalić czy treść wizualna wzbogacona dodatkową narracją pomaga widzom zapamiętać informacje zawarte w scenie. Pytanie stworzone było w formie otwartej, dając osobom badanym pełną dowolność celem uniknięcia zasugerowania jakiekolwiek odpowiedzi. Pytanie brzmiało: Ile par butów przymierzyla Eva?

Prawidłową odpowiedzią na to pytanie jest: cztery pary, jednak tabela poniżej zawiera dodatkowe odpowiedzi, które udzielane były przez osoby badane. Zestawienie osób wraz $\mathrm{z}$ ich procentowym rozkładem przedstawione jest $\mathrm{w}$ tabeli poniżej (patrz Tabela 2).

Tabela 2. Ankieta 1 - Pytanie nr 2a

\begin{tabular}{|l|c|c|c|c|c|c|}
\hline & $15-19$ & $20-29$ & $30-39$ & $40-49$ & $50-59$ & $60+$ \\
\hline 3 pary & 0 & $1(12,5 \%)$ & 0 & 0 & 0 & 0 \\
\hline 4 pary & $2(100 \%)$ & $5(62,5 \%)$ & $3(60 \%)$ & $4(100 \%)$ & $3(75 \%)$ & $1(33,3 \%)$ \\
\hline 5 par & 0 & $2(25 \%)$ & $2(40 \%)$ & 0 & $1(25 \%)$ & $2(66,7 \%)$ \\
\hline
\end{tabular}


$100 \%$ prawidłowych odpowiedzi - cztery pary - udzieliły wszystkie osoby z przedziału wiekowego 15-19 oraz 40-49. U osób w wieku 20-29 62,5\% stanowiły prawidłowe odpowiedzi, jednak jedna osoba wskazała na trzy pary, a dwie osoby na pięć par. Poprawnej odpowiedzi w przedziale wiekowym 30-39 udzieliło 60\% osób, pozostałe $40 \%$ wskazało na pięć par butów. Spośród czterech osób w wieku 50-59 jedna osoba wpisała pięć par, z kolei osoby powyżej 60 roku życia wskazywały kolejno w 33,3\% na cztery pary butów oraz w $66,7 \%$ na pięć par.

\subsubsection{Pytanie ankietowe $\mathrm{nr} 3 \mathrm{a}$}

Pytanie trzecie w ankiecie również stworzone zostało w celu określenia poziomu zapamiętania informacji przedstawionej w scenie. Analogicznie do poprzedniego pytania, to również zostało stworzone w wersji otwartej, by osoby badane nie miały możliwości sugerowania się gotowymi odpowiedziami, co mogłoby jednocześnie zniekształcić analizę wyników badania. Pytanie brzmiało: Ile osób brało udziat w scenie?

Prawidłowa odpowiedź na to pytanie to: trzy osoby, jednak tabela (patrz Tabela 3) poniżej zawiera również inne warianty, które wpisywane były przez grupę badanych. Wyniki dla poszczególnych przedziałów wiekowych przedstawiają ilość osób udzielających danej odpowiedzi wraz z ich procentowym rozkładem.

Tabela 3. Ankieta 1 - Pytanie nr 3a

\begin{tabular}{|l|c|c|c|c|c|c|}
\hline & $15-19$ & $20-29$ & $30-39$ & $40-49$ & $50-59$ & $60+$ \\
\hline Dwie osoby & 0 & 0 & 0 & 0 & $1(25 \%)$ & 0 \\
\hline Trzy osoby & $2(100 \%)$ & $8(100 \%)$ & $5(100 \%)$ & $4(100 \%)$ & $3(75 \%)$ & $3(100 \%)$ \\
\hline
\end{tabular}

Prawidłową odpowiedź udzieliły w $100 \%$ osoby z przedziałów wiekowych 15-19, 20-29, 30-39, 40-49 oraz 60+. Z czterech osób w wieku 50-59 jedna osoba wpisała inną odpowiedź - dwie osoby.

\subsubsection{Pytanie ankietowe $\mathrm{nr} 3 \mathrm{a}$}

Ostatnie pytanie (pytanie nr 3) przeznaczone było tylko dla osób z grupy oglądającej film z AD, gdyż analiza udzielanych odpowiedzi miała przedstawić ocenę dodatkowej narracji przez badanych. Wynik ogólny wraz z procentowym rozkładem przedstawiony jest $\mathrm{w}$ tabeli poniżej (patrz Tabela 4). 
Tabela 4. Ankieta 1 - Pytanie nr 3 (poziom zadowolenia z audio deskrypcji)

\begin{tabular}{|l|c|}
\hline & Wynik ogólny \\
\hline Bardzo pomocna & $8(30,8 \%)$ \\
\hline Raczej pomocna & $9(34,6 \%)$ \\
\hline Nie mam zdania & $3(11,5 \%)$ \\
\hline Raczej zbędna & $4(15,4 \%)$ \\
\hline Bardzo zbędna & $2(7.7 \%)$ \\
\hline
\end{tabular}

Analiza powyższego pytania zamkniętego wskazuje na ogólny pozytywny odbiór audiodeskrypcji. Kolejno 30,8\% osób oceniło ją jako bardzo pomocna, 34,6\% jako raczej pomocną. Jako raczej zbędna audiodeskrypcję opisuje 15,4\% badanych, z kolei 7,7\% zaznaczyło odpowiedź bardzo zbędna. Zdania nie wyraziło 11,5\% osób.

Szczegółowy rozkład odpowiedzi z podziałem na sześć przedziałów wiekowych znajduje się w tabeli poniżej (patrz Tabela 5).

Tabela 5. Ankieta 1 - Poziom zadowolenia z audiodeskrypcji (szczegółowy rozkład odpowiedzi z podziałem na wiek)

\begin{tabular}{|l|c|c|c|c|c|c|}
\hline & $15-19$ & $20-29$ & $30-39$ & $40-49$ & $50-59$ & $60+$ \\
\hline Bardzo pomocna & 0 & $2(25 \%)$ & $1(20 \%)$ & 0 & $2(50 \%)$ & $3(100 \%)$ \\
\hline Raczej pomocna & $1(50 \%)$ & $3(37,5 \%)$ & $2(40 \%)$ & $2(50 \%)$ & $1(25 \%)$ & 0 \\
\hline Nie mam zdania & $1(50 \%)$ & $1(12,5 \%)$ & 0 & $1(25 \%)$ & 0 & 0 \\
\hline Raczej zbędna & 0 & $1(12,5 \%)$ & $1(20 \%)$ & $1(25 \%)$ & $1(25 \%)$ & 0 \\
\hline Bardzo zbędna & 0 & $1(12,5 \%)$ & $1(20 \%)$ & 0 & 0 & 0 \\
\hline
\end{tabular}

Najliczniejsza grupa (100\%) oceniająca AD za bardzo pomocna to osoby w wieku 60+. Kolejno 50\% osób z przedziałów wiekowych 15-19 i 40-49 najczęściej określa AD jako raczej pomocną. Negatywną ocenę w największym stopniu stanowią odpowiedzi osób w wieku 40-49 (25\%), 50-59 (25\%) oraz 30-39 (20\%).

\subsection{Ankieta 2 - wersja bez audiodeskrypcji}

Drugą wersję ankiety otrzymały osoby, które przydzielone zostały losowo do grupy mającej za zadanie obejrzenie fragmentu filmu Imagine bez dodatkowej narracji. Ankieta składała się z trzech pytań, w tym dwa pytania były otwarte a jedno jedno pytanie wykorzystało tzw. pięciostopniową skalę Likerta. 


\subsubsection{Pytanie ankietowe $\mathrm{nr} 1 \mathrm{~b}$}

Pytanie pierwsze, analogicznie do pierwszej wersji ankiety, stanowi tzw. pięciostopniową skalę Likerta, która zawiera dziesięć tych samych przymiotników o różnym nacechowaniu, mająca na celu zbadać poziom zadowolenia $\mathrm{z}$ obejrzanego fragmentu filmu. Poniższa tabela zawiera średnie arytmetyczne obliczone dla poszczególnych przedziałów wiekowych (patrz Tabela 6).

Tabela 6. Ankieta 2 - Pytanie nr 1b (skala Likerta)

\begin{tabular}{|l|c|c|c|c|c|c|}
\hline & $15-19$ & $20-29$ & $30-39$ & $40-49$ & $50-59$ & $60+$ \\
\hline Interesujący & 2 & 3,71 & 3,75 & 3,2 & 3,5 & 1,5 \\
\hline Nużący & 4,33 & 2,14 & 1,75 & 2 & 2,75 & 3,5 \\
\hline Irytujący & 3,3 & 1,86 & 1,75 & 1,4 & 1,75 & 1,5 \\
\hline Wciągający & 1,67 & 3,43 & 3,5 & 2,4 & 3,25 & 1 \\
\hline Przyjemny & 1,67 & 3,43 & 3,5 & 3 & 3,5 & 3 \\
\hline Wolny & 4,67 & 2,57 & 1,75 & 2 & 3 & 1,5 \\
\hline Gwałtowny & 1 & 1,29 & 1,5 & 1,2 & 1,25 & 2,5 \\
\hline Ciężki & 2 & 1,29 & 1,75 & 2,4 & 2,25 & 3 \\
\hline Krótki & 1 & 3,57 & 3,75 & 3,8 & 3,75 & 2 \\
\hline Długi & 3,67 & 1,86 & 1,75 & 1,8 & 1,75 & 4,5 \\
\hline
\end{tabular}

Analizując wyniki uzyskane dla poszczególnych przymiotników, osoby w wieku $60+$ obejrzany fragment najczęściej opisywały jako gwałtowny, ciężki oraz dlugi. Dla badanych w wieku 50-59 film był przyjemny, z kolei dla osób 40-49 był on krótki. Pozytywnie o scenie wypowiadały się osoby w wieku 30-39, wybierając najczęściej słowa interesujacy, wciagajacy, przyjemny. Z kolei przymiotniki nużacy, irytujący, wolny najliczniej zaznaczane były przez osoby w wieku 15-19.

\subsubsection{Pytanie ankietowe $\mathrm{nr} 2 \mathrm{~b}$}

Pytanie drugie, będące pytaniem otwartym, sprawdzało w jakim stopniu widzowie byli w stanie zapamiętać szczegółowe informacje dotyczące sceny bez dodatkowej pomocy ze strony audiodeskryptora. Podobnie jak w pierwszej grupie badawczej, osoby oglądające film bez dodatkowej narracji oprócz prawidłowej odpowiedzi - bohaterka łącznie przymierzała cztery pary butów - także wpisywały inne warianty, które zawarte są w tabeli poniżej (patrz Tabela 7).

$\mathrm{Z}$ poniższej tabeli wynika, że żadna $\mathrm{z}$ grup wiekowych nie zaznaczyła $\mathrm{w} 100 \%$ prawidłowej odpowiedzi. Najtrafniej odpowiedziały osoby w wieku $50-59$ (75\% pra- 
Tabela 7. Ankieta 2 - Pytanie nr $2 \mathrm{~b}$

\begin{tabular}{|c|c|c|c|c|c|c|}
\hline & $15-19$ & $20-29$ & $30-39$ & $40-49$ & $50-59$ & $60+$ \\
\hline 3 pary & $1(33,3 \%)$ & $3(37,5 \%)$ & 0 & $1(20 \%)$ & $1(25 \%)$ & $2(100 \%)$ \\
\hline 4 pary & $2(66,7 \%)$ & $5(62,5 \%)$ & $2(66,7 \%)$ & $3(60 \%)$ & $3(75 \%)$ & 0 \\
\hline 5 par & 0 & 0 & $1(33,3 \%)$ & $1(20 \%)$ & 0 & 0 \\
\hline
\end{tabular}

widłowych odpowiedzi), w dalszej kolejności (66,7\%) dobrze odpowiadały osoby w przedziałach wiekowych 15-19 oraz 30-39. I 62,5\% w grupie wiekowej 20-29.

Jednak w każdej z tych grup wiekowych przynajmniej jedna osoba wskazywała także nieprawidłowo na trzy pary i pięć par butów. Najwięcej rozbieżności w odpowiedziach widoczne jest w przedziale 40-49 lat, jako że oprócz 60\% prawidłowych odpowiedzi, 20\% wskazywało na trzy pary i pięć par. Najsłabsze wyniki zaobserwować można w najstarszej grupie wiekowej, gdyż tam wszystkie osoby wpisały odpowiedź niezgodną z treścią zaprezentowanej sceny.

\subsubsection{Pytanie ankietowe $\mathrm{nr} 3 \mathrm{~b}$}

Trzecie pytanie to pytanie otwarte. Osoby badane miały za zadanie wpisać ilość osób, które widziały w obejrzanym fragmencie filmu. Podobnie jak w pierwszej wersji ankiety, osoby badane wpisywały nie tylko prawidłową odpowiedź - trzy osoby - ale pośród odpowiedzi obecne były też inne warianty. Otrzymane wyniki przedstawione są w tabeli poniżej (patrz Tabela 8).

Jedyną grupą wiekową, która wskazała w 100\% prawidłową odpowiedź była grupa wiekowa 30-39. 80\% prawidłowych odpowiedzi udzieliły osoby z grupy wiekowej 40-49, natomiast odpowiedź w grupach 20-29 i 50-59 stanowiła po 75\%. Obydwie osoby w wieku $60+(100 \%)$ wpisały błędną odpowiedź - wskazały one dwie osoby widoczne na ekranie.

Tabela 8. Ankieta 2 - Pytanie nr $3 b$

\begin{tabular}{|l|c|c|c|c|c|c|}
\hline & $15-19$ & $20-29$ & $30-39$ & $40-49$ & $50-59$ & $60+$ \\
\hline Dwie osoby & $1(33,3 \%)$ & $2(25 \%)$ & 0 & $1(20 \%)$ & $1(25 \%)$ & $2(100 \%)$ \\
\hline Trzy osoby & $2(66,7 \%)$ & $6(75 \%)$ & $3(100 \%)$ & $4(80 \%)$ & $3(75 \%)$ & 0 \\
\hline
\end{tabular}

\subsection{Analiza porównawcza - zestawienie wyników}

Przeprowadzona wstępna analiza porównawcza trzech pytań będących częścią obydwu wersji ankiet - dwóch pytań otwartych oraz wyników uzyskanych za pomocą tzw. skali Likerta miała na celu ustalić rolę i wpływ audiodeskrypcji na odbiór treści filmu przez osoby widzące 


\subsubsection{Skala Likierta}

Poniższa tabela przedstawia zestawienie wyników pięciostopniowej skali Likerta uzyskanych $\mathrm{w}$ dwóch wersjach ankiety $-\mathrm{z}$ audiodeskrypcją i bez audiodeskrypcji. Wyniki uzyskane dla poszczególnych przymiotników w kolumnach $z$ audiodeskrypcja i bez audiodeskrypcji stanowią średnią arytmetyczną odpowiedzi wszystkich osób z danej grupy badawczej, z kolei kolumna wynik ogólny stanowi różnicę między średnimi arytmetycznymi obydwu grup dla poszczególnych przymiotników (patrz Tabela 9).

Tabela 9. Zestawienie wyników ankiety nr 1 i nr 2 (skala Likerta)

\begin{tabular}{|l|c|c|c|}
\hline & Wersja z audiodeskrypcją & Wersja bez audiodeskrypcji & Wynik ogólny \\
\hline Interesujący & 3,85 & 3,2 & 0,65 \\
\hline Nużący & 1,62 & 2,52 & 0,9 \\
\hline Irytujący & 1,92 & 1,88 & 0,04 \\
\hline Wciągający & 3,92 & 2,8 & 1,12 \\
\hline Przyjemny & 3,77 & 3,12 & 0,65 \\
\hline Wolny & 1,65 & 2,56 & 0,91 \\
\hline Gwałtowny & 1,54 & 1,36 & 0,18 \\
\hline Ciężki & 1,65 & 1,96 & 0,31 \\
\hline Krótki & 3,08 & 3,24 & 0,16 \\
\hline Długi & 1,62 & 2,24 & 0,62 \\
\hline
\end{tabular}

Największą rozbieżność wyników zauważyć można w ocenie fragmentu filmu jako wciagającego - grupa, której zadaniem było obejrzeć scenę z dodatkową narracją częściej zgadzała się z tym określeniem $(3,92)$ niż grupa $\mathrm{z}$ filmem bez audiodeskrypcji $(2,8)$. Znaczna różnica $\mathrm{w}$ ocenie widoczna jest także w przypadku przymiotników nużący oraz wolny - w ten sposób fragment filmu zdecydowanie częściej oceniany był przez grupę osób oglądających film bez dodatkowej narracji.

Pozostałe różnice uzyskane w analizie wyników wskazują, że grupa osób wypełniających pierwszą wersję ankiety - z audiodeskrypcją - częściej oceniała obejrzany materiał jako interesujacy, przyjemny, ale także gwattowny i irytujacy. Z kolei w grupie drugiej - bez audiodeskrypcji - przeważały przymiotniki ciężki, krótki, dtugi.

\section{Pytanie otwarte nr $1 \mathrm{a}$ i $1 \mathrm{~b}$}

Poniższa tabela obrazuje zestawienie odpowiedzi udzielanych na pytanie Ile par butów przymierzyła Eva? w dwóch wersjach ankiety - z audiodeskrypcją i bez audiodeskrypcji. Przestawione zostały dwie formy wyników - ilość osób udzielających 
danej odpowiedzi oraz znajdujący się w nawiasach rozkład procentowy odpowiedzi (patrz Tabela 10).

Prawidłową odpowiedź na pytanie ankietowe - cztery pary - częściej zaznaczała grupa badanych, która oglądała film z dodatkowym komentarzem AD (69,2\% całej grupy). Grupa druga, oglądająca scenę bez $\mathrm{AD}$, osiągnęła niższe wyniki $(60 \%$ całej grupy udzieliło prawidłowej odpowiedzi).

Tabela 10. Zestawienie wyników ankiety 1 i 2 - Pytanie nr 2a i 2b

\begin{tabular}{|c|c|c|}
\hline & Wersja z audiodeskrypcją & Wersja bez audiodeskrypcji \\
\hline 3 pary & $1(3,89 \%)$ & $8(32 \%)$ \\
\hline 4 pary & $18(69,2 \%)$ & $15(60 \%)$ \\
\hline 5 par & $7(26,9 \%)$ & $2(8 \%)$ \\
\hline
\end{tabular}

W przypadku obydwu grup uczestnicy badania udzielali również nieprawidłowych odpowiedzi, wśród których pojawiały się warianty trzech oraz pięciu par butów. Grupa pierwsza, wspomagana przez AD, częściej wskazywała na pięć par $(26,9 \%)$, natomiast według $32 \%$ grupy drugiej bohaterka przymierzyła trzy pary obuwia.

\section{Pytanie otwarte nr 2a i $2 b$}

Wyniki zaprezentowane w tabeli poniżej (Tabela 11) zawierają zestawienie odpowiedzi dwóch grup badawczych na pytanie ankietowe Ile osób brało udziat $w$ scenie?. Analogicznie do poprzedniego zestawienia, tabela przedstawia wyniki $\mathrm{w}$ dwóch formach - ilość osób $\mathrm{w}$ grupach $\mathrm{z}$ audiodeskrypcją i bez audiodeskrypcji udzielających danej odpowiedzi, oraz wynik procentowy znajdujący się $\mathrm{w}$ nawiasach.

Tabela 11. Zestawienie wyników ankiety 1 i 2 - Ile osób brało udział w scenie?

\begin{tabular}{|c|c|c|}
\hline & Wersja z audiodeskrypcją & Wersja bez audiodeskrypcji \\
\hline Dwie osoby & $1(3,8 \%)$ & $7(28 \%)$ \\
\hline Trzy osoby & $25(96,2 \%)$ & $18(72 \%)$ \\
\hline
\end{tabular}

Prawidłowa odpowiedź - trzy osoby - w zdecydowanej większości, bo aż 96,2\%, zaznaczona była w grupie osób oglądających fragment filmu Imagine z AD. Odpowiedź ta w drugiej grupie udzielona została w $72 \%$. 
W obydwu grupach udzielone zostały także nieprawidłowe odpowiedzi. Według jednej osoby $(3,8 \%)$ oglądającej materiał z AD, w scenie brały udział dwie osoby. $\mathrm{Z}$ kolei tej samej odpowiedzi w drugiej grupie udzieliło $28 \%$ osób.

\section{Podsumowanie}

Głównym celem niniejszego wstępnego badania było zbadanie obecności i roli audiodeskrypcji jako elementu mediującego w akcie komunikacyjnym osób widzących, poprzez sprawdzenie jej wpływu na ilość zapamiętanych informacji oraz określenie czy jej obecność wpływa na zadowolenie widzów z odbioru treści audiowizualnej. Dane zebrane $\mathrm{w}$ toku pilotażowego badania pozwoliły na wyciągnięcie poniższych wniosków.

Założenie dotyczące korzystnego wpływu mediacji AD na zapamiętanie szczegółów dotyczących filmu okazało się trafne. Potwierdziły to wyniki otrzymane w ankietach, które wykazały znaczne dysproporcje pomiędzy odpowiedziami osób oglądających fragment filmu Imagine z AD oraz oglądających ten sam fragment bez AD. Uzyskane wyniki można thumaczyć specyfiką tego rodzaju przekazu, który kierowany jest przez dwie modalności - audio-wokalną oraz wizualno-dotykową, Innymi słowy, kiedy dźwięk dopełniony jest obrazem, ma to korzystny wpływ na takie procesy jak zapamiętywanie czy przypominanie - zjawisko to nazywa się podwójnym kodowaniem (ang. dual coding) (zob. Sadowska, 2015). W ślad za tą teorią, kiedy obrazy przedstawione $\mathrm{w}$ filmie wsparte są dodatkowym komentarzem, w którym AD będąca swoistym mediatorem dodatkowo opisuje warstwę wizualną, proces komunikacyjny zachodzący między twórcą filmu (lub między samym filmem) a widownią bez dysfunkcji wzroku staje się bardziej efektywny.

Założenie drugie, dotyczące wzrostu satysfakcji z obecności AD również zostało potwierdzone. Porównując wyniki uzyskane w pięciostopniowej skali Likerta zastosowanej w obydwu wersjach ankiety zauważyć można, że osoby oglądające scenę filmu Imagine częściej opisywały ją w sposób pozytywny, w odróżnieniu do osób uczestniczących w pokazie bez AD. I tak, grupa z dodatkową narracją częściej oceniała fragment jako wciągający, interesujący oraz przyjemny, w momencie gdy druga grupa określała tę samą scenę jako nużącą, ciężką, krótką, oraz co interesujące, również długą. Biorąc także pod uwagę analizę rozkładu odpowiedzi w zależności od przedziału wiekowego dojść można do wniosku, że istnieją pewne przesłanki umożliwiające potwierdzenie postawionej hipotezy, jako że osoby badane będące w przedziale wiekowym $60+$ opisywały scenę jako interesującą i przyjemną, osoby w wieku 50-59 lat określały ją jako wciągającą, z kolei pozostałe osoby częściej wybierały negatywne przymiotniki opisujące scenę. $Z$ tego względu, pytaniem rozstrzygającym o potwierdzeniu hipotezy okazało się dodatkowe pytanie zawarte 
w ankiecie przeznaczonej dla widzów oglądających fragment filmu z AD. Otrzymane wyniki wskazują na dużą satysfakcję najstarszej grupy wiekowej, ale również osób w wieku 40-49 lat oraz, co ciekawe, przez najmłodszą grupę.

\section{Bibliografia}

Imagine. 2012. Reż. Andrzej Jakimowski, Polska: KMBO Production.

Bardini, F. 2017. „Audio description style and the film experience of blind spectators: design of a reception study“. Rivista Internazionale di Tecnica della Traduzione/International Journal of Translation 19. 49-73.

Braun, S. 2007. „Audio description from a discourse perspective: a socially relevant framework for research and training". Linguistica Antverpiensia. New Series 6. Themes in Translation Studies. $357-369$.

Braun, S. 2008. „Audiodescription research: state of art and beyond”. Translation Studies in the New Millennium 6. 14-30.

Braun, S. 2011. „Creating coherence in audio description”. Meta: Journal des Traducteurs/ Meta: Translator's Journal 56.3. 645-662.

Chmiel, A. i I. Mazur 2014. Audiodeskrypcja. Poznań: Wydział Anglistyki UAM.

Emmitt, S. i Ch.A. Gorse. 2007. Communication in construction teams. New York: Taylor and Francis.

Emmitt, S. i Ch.A. Gorse. 2009. Construction communication. Oxford: Blackwell Publishing Limited.

Fryer, L. 2016. An introduction to audiodescription: a practical guide. London/New York: Routledge.

Hendrykowski, M. 2018. Scenariusz filmowy. Teoria i praktyka. Poznań: Wydawnictwo Naukowe UAM.

Hirvonen, M. i L. Tiittula. 2010. "A method for analysing multimodal research material: Audio description in focus". Electronic proceedings of the KäTu symposium on translation and interpreting studies 4. 1-12. (https://www.sktl.fi/@Bin/40698/Hirvonen\%26Tiittula_MikaEL2010.pdf) (data dostępu: 02.09.2019).

Hyks, V. 2005. "Audio description and translation. Two related but different skills". Translating Today 4. $6-8$.

Iglesias Fernández, E., Martínez Martínez, S. i A.J. Chica Núñez. 2015. „Cross-fertilization between reception studies in audio description and interpreting quality assessment: the role of the describer's voice". W zbiorze: Baños Piñero, R. i J. Díaz-Cintas (red.). Audiovisual Translation in a Global Context. Basingstoke: Palgrave Macmillan. 72-95.

Janowska, I. 2017. „Mediacja i działania mediacyjne w dydaktyce języków obcych”. Języki Obce w Szkole 3. 80-86.

Jankowska, A. 2009. „Audiodeskrypcja - wzniosły cel w thumaczeniu”. W zbiorze: Brzozowski, J. i M. Filipowicz-Rudek (red.). Między oryginatem a przektadem: wzniostość i styl wysoki w przekładzie. Kraków: Księgarnia Akademicka. 225-256.

Jankowska, A. 2014. „Tłumaczenie jako alternatywna metoda tworzenia audiodeskrypcji”. Przekladaniec 28. 23-28.

Kalisz, A. i A. Zienkiewicz. 2014. Mediacja sądowa i pozasądowa. Zarys wykladu. Warszawa: Wolters Kluwer SA.

Kowalewska, K. i J. Puppel. 2017. „Wizerunek i wskaźnikowość układów ciała ludzkiego w reklamie na przykładzie polskiej prasy kobiecej - badanie i uwagi wstępne”. Scripta Neophilologica Posnaniensia XVII. 495-502.

Künstler, I. 2014. „Cel uświęca środki audiodeskrypcji”. Przektadaniec 28. 140-152. 
Künstler, I., Butkiewicz, U. i R. Więckowski. 2012. Audiodeskrypcja - standardy tworzenia. Warszawa: Fundacja Kultury bez Barier. (https://www.nimoz.pl/files//articles/147/Audiodeskrypcja_-_zasady_ tworzenia.pdf) (data dostępu: 10.02.2019).

Mazur, I. 2014a. „Gestures and facial expressions in audio description”. W zbiorze: Maszerowska, A, Matamala, A. i P. Orero. (red). 2014. Audiodescription: new perspectives illustrated. Amsterdam/Philadelphia: John Benjamins Publishing Company. 179-198.

Mazur, I. 2014b. „Projekt ADLAB i funkcjonalizm w przekładzie - w stronę strategii audiodeskrypcyjnych". Przektadaniec 28. 11-22.

Mazur, I. i A. Chmiel. 2011. „Odzwierciedlenie percepcji osób widzących w opisie dla osób niewidomych. Badania okulograficzne nad audiodeskrypcją". Lingwistyka Stosowana / Applied Linguistics / Angewandte Linguistik 4. 163-180.

Mazur, I. i A. Chmiel. 2012. "Audiodescription made to measure: Reflections on interpretation in AD based on the Pear Tree Project Data". W zbiorze: Remael A., Orero P. i M. Carroll (red.). Audiovisual translation and media accessibility at the crossroads. Media for all 3. Amsterdam/New York: Rodopi. 173-188.

Orero, P. 2007. „Sampling audio description in Europe”. W zborze: Díaz-Cintas, J., Orero, P. i A. Remael (red.). Media for all: Subtitling for the deaf, Audiodescription, and sign language. Amsterdam/New York: Rodopi. 111-126.

Orero, P. 2012. "Film reading for writing audio descriptions: A word is worth a thousand images?". W zbiorze: Perego, E. (red.). Emerging topics in translation: audiodescription. Trieste: EUT Edizioni Università di Triestepp. 13-28.

Orero, P. i A. Matamala. 2013. „Standardising audio description”. Italian Journal of Special Education for Inclusion 1.1. 149-155.

Pązik, A. 2008. „Przedmiot i podmiot prawa do wizerunku”. Internetowy Przeglad Prawniczy TBSP UJ 1. $126-151$.

Perego, E. (red.). 2012. Emerging topics in translation: audiodescription. Trieste: EUT Edizioni Università di Triestepp.

Perego, E. 2016. "Gains and losses of watching audio described films for sighted viewers". Target 28(3). 424-444.

Puigdomènech, L., Matamala, A. i P. Orero. 2010. „Audiodescription of films: state of the art and a protocol proposal". Studies in Language 20. 27-43.

Puppel, S. (red). 2011. Transkomunikacja. W strone sprofilowania przestrzeni publicznej jako wieloplaszczyznowej przestrzeni komunikacyjnej. Scripta de Communicatione Posnaniensi. Seria: Prace Naukowe Katedry Ekokomunikacji. Tom 3. Poznań: KEKO UAM.

Puppel, S. 2016. „Kuźnia Hefajstosa czyli krótki zarys teorii wizerunku w komunikacji człowieka”. Scripta Neophilologica Posnaniensia XVI. 109-124.

Rabbitt, P.M.A. i A.R. Carmichael. 1995. "Designing communications and information handling systems for disabled and elderly users". W zbiorze: Snel, J. i R. Cremer (red.) Work and aging: a European perspective. London: Taylor and Francis. 173-195.

Sadowska, A. 2014. „Audiodeskrypcja do ilustracji w prasie - wskazówki dla trenerów szkolących audiodeskryptorów". Przekładaniec 28. 124-139.

Sadowska, A. 2015. „Learning English vocabulary from film audio description: a case of Polish sighted students". Roczniki Humanistyczne 63.11. 101-123

Shannon, C.E. i W. Weaver. 1949. The mathematical theory of communication. Champaign, Ill.: University of Illinois Press.

Sikorski, J. 2014. „Wizerunek brzmienia wypowiedzi w nauce wymowy. Ewaluacyjna bariera między kategoryzacją a instrukcją wykonawczą w procedurze imitacyjnej”. Konińskie Studia Językowe 2.1. $55-69$. 
Ślęzak, P. 2009. Ochrona prawa do wizerunku. Katowice: Wydawnictwo Uniwersytetu Śląskiego.

Snel, J. i R. Cremer (red.) 1995. Work and aging: a European perspective. London: Taylor and Francis.

Snyder, J. 2008. „Audiodescription. The visual made verbal”. W zbiorze: Díaz-Cintas, J. (red.). The didactics of audiovisual translation. Amsterdam/Philadelphia: John Benjamins Publishing Company. 191-198.

Snyder, J. 2015. Przekuć obraz w słowo: wokót historii i współczesnych zastosowań audiodeskrypcji. San Diego: Academic Press.

Szarkowska, A. 2011. „Text-to-speech audio description: towards wider availability of AD”, The Journal of Specialised Translation 15. 142-162.

Szarkowska, A. i A. Jankowska. 2012. „Text-to-speech audio description of voiced-over films. A case study of audio described Volver in Polish". W zbiorze: Perego, E. (red.). Emerging topics in translation: audiodescription. Trieste: EUT Edizioni Università di Trieste. 81-98.

Szarkowska, A. i A. Jankowska. 2015. „Audio describing foreign films”. The Journal of Specialised Translation 23. 243-269.

Szarkowska, A. i I. Künstler. 2012. „Audiodeskrypcja w kinie, teatrze i muzeum: wprowadzenie do działań praktycznych”. W zbiorze: Trzeciakiewicz, M. (red.). Audiodeskrypcja w teorii i praktyce, czyli jak mówić o tym, czego nie można zobaczy. Wrocław: Fundacja Katarynka. 65-107. 